\title{
Ovarian tissue vitrification is more efficient than slow freezing to preserve ovarian stem cells in CF-1 mice
}

Paula Barros Terraciano ${ }^{1,2}$, Tuane Alves Garcez ${ }^{1}$, Markus Berger ${ }^{1,2}$, Isabel Durli ${ }^{1,2}$, Cristiana Palma Kuhl ${ }^{1}$, Vitória de Oliveira Batista ${ }^{1}$, Raquel de Almeida Schneider ${ }^{1}$, Jaquelline Festa ${ }^{1}$, Emily Pilar ${ }^{4}$, Marcela Goulart ${ }^{1}$, Charles Ferreira ${ }^{2}$, Eduardo Pandolfi Passos ${ }^{1,2}$, Elizabeth Cirne Lima ${ }^{1,2,3}$

\footnotetext{
${ }^{1}$ Centro de Pesquisa Experimental, Laboratório de Embriologia e Diferenciação Celular, Hospital de Clínicas de Porto Alegre, Brazil.

2 Programa de Pós Graduação em Ciências da Saúde: Ginecologia e Obstetrícia, Universidade Federal do Rio Grande do Sul, Brazil.

${ }^{3}$ Departamento de Patologia Clínica, Faculdade de Veterinária, Universidade Federal do Rio Grande do Sul, Brazil.

${ }^{4}$ Centro de Pesquisa Experimental, Unidade de Patologia Experimental, Hospital de Clínicas de Porto Alegre, Brazil.
}

This study was presented in the $37^{a}$ Semana Científica do Hospital de Clínicas de Porto Alegre

\begin{abstract}
Objective: The aim of this study was to investigate the efficacy of protocols for mice ovary cryopreservation to compare the differences in Mouse Vasa Homologue expression (a germline cell marker) and ovarian viability after vitrification or slow freezing.

Methods: Female CF1 mice aged 40-45 days were randomly divided into three groups: Control, vitrification or slow freezing. Their ovaries were surgically removed, rinsed in saline solution and cryopreserved. For vitrification, we used a commercial protocol and for slow freeze, we used $1.5 \mathrm{M}$ ethylene glycol (EG) as cryoprotectant. After that, the ovaries were processed for histological an immunohistochemical analysis, and counting of primordial, primary, pre-antral and antral follicles.

Results: No significant difference was found in the proportion of high-quality primordial, primary and pre-antral follicles after thawing/warming in the slow freezing and vitrification groups. The immunohistochemistry for $\mathrm{MVH}$ antibody demonstrated that the slow freeze group had a higher number of unmarked cells $(p=0.012)$, indicating a harmful effect on the MVH expression in the ovarian tissue, where the cell structure is complex.

Conclusion: Although both protocols indicated similar results in the histological analysis of follicular counts, the vitrification protocol was significantly better to preserve ovarian stem cells, an immature germ cell population. These cells are able to self-renew having regeneration potential, and may be effective for the treatment of ovarian failure and consequently infertility.
\end{abstract}

Keywords: ovary, vitrification, stem cell

\section{INTRODUCTION}

Ovarian transplantation has been used for many years in animal models to study ovarian endocrine function (Bagwell et al., 1976), and it was later adapted for ovarian function studies after cryopreservation (Sugimoto et al., 2000). Ovarian cryopreservation research is performed for the purpose of strain preservation (Dorsch et al., 2004) and to optimize the procedure for use in human female fertility preservation programs (Demeestere et al., 2009). Fertility preservation in human female aims to preserve/ restore fertility in girls and young adult women planned to undergo potentially gonadotoxic cancer therapy (Meirow \& Nugent, 2001; Bastings et al., 2016; Donnez et al., 2011). However, only a very limited number of live births have been reported and it is most likely that a large number of transplantation attempts have been performed; the procedure still needs further development to increase its effectiveness. Factors that should be improved are cryopreservation protocols and surgical transplantation procedures (Kagawa et al., 2009; Sheikhi et al., 2011; Ackermann et al., 2017).

Most of the follicular loss in cryopreserved tissue does not occur during the cryopreservation/thawing processes, but rather during the warm ischemic time after retransplantation (Liu et al., 2002; Gosden, 2000). Interventions such as transplantation to granulation tissue (Israely et al., 2006) or incubation of the pretransplantation tissue with growth factors (Schnorr et al., 2002), vitamin E (Nugent et al., 1998), or other antioxidants (Weissman et al., 1999; Kim et al., 2004; Sapmaz et al., 2003) have shown moderate or no effect to increase follicular survival. Whole ovary transplantation has been suggested as an approach to overcome the deleterious effects of prolonged ischemic time after the tissue reintroduction (Jadoul et al., 2007; Martinez-Madrid et al., 2007; Bedaiwy \& Falcone, 2010; Bromer \& Patrizio, 2009). Thus, alternative techniques for whole ovary cryopreservation and transplantation with vascular anastomosis should be stimulated (Silber et al., 2008; Imhof et al., 2006; Wang et al., 2002). Indeed, live births have been demonstrated after whole ovary cryopreservation and vascular retransplantation, both in sheep (Imhof et al., 2006) and in rat models (Silber et al., 2008), although the procedure as a whole has low effectiveness, leading to low live-birth rates.

Considering the difficulties of ovarian tissue transplantation techniques, improvements in cryopreservation procedures are needed. Therefore, the aim of this study was to investigate the efficacy of protocols for cryopreservation of mice ovary, and compare the differences in Mouse Vasa Homologue expression (a germline cell marker) and ovarian viability after vitrification or slow freezing.

\section{MATERIALS AND METHODS}

\section{Animals}

Female CF-1 mice, aged 28 to 30 days with average weight of $29.29 \pm 2.9 \mathrm{~g}$, were used. The animals were kept in group cages under controlled conditions $\left(23^{\circ} \mathrm{C}\right.$ and $12-$ 
hour light/dark cycles). They were fed pelleted food and tap water ad libitum. After an acclimatization period, the mice were randomly divided into three groups and were submitted to vaginal cytology, for confirmation of the estrous cycle before euthanize, with isoflurane overdoses, to remove the ovaries for experiments. The Animal Ethics Commission of HCPA (CEUA-HCPA 16-0169) approved these experiments.

\section{Experimental Groups}

The experiment was designed to compare the viability and MVH expression by ovarian cells after different cryopreservation processes. Each group consisted of ten animals ( $n=20$ ovaries) randomly allocated to the following groups: fresh control ovaries (C) or ovaries cryopreserved by either vitrification (VIT) or slow-freezing (SF).

\section{Ovaries}

The ovaries were collected after slaughtering the animals by anesthetic overdose with isoflurane $(5-10 \%$ at $100 \% \mathrm{O}_{2}$ ), and they were dissected to remove adipose and mesenteric tissue. Immediately after, the ovaries were submitted to cryopreservation according with their experimental group. The right and left ovaries of the same animal were separately cryopreserved for different analysis.

\section{Cryopreservation}

Whole ovaries subjected to slow freezing (SF) were incubated for $15 \mathrm{~min}$ in DMEM supplemented with $1.5 \mathrm{M}$ Ethylene Glycol (EG) and $0.5 \mathrm{M}$ sucrose at $4^{\circ} \mathrm{C}$, added to $1.5 \mathrm{~mL}$ cryovials containing $1.5 \mathrm{M}$ EG solution $(0.5 \mathrm{~mL})$ and placed into a container at room temperature (Cryo Freezing Container; Nalgene) with isopropanol. The container was placed in a $-80^{\circ} \mathrm{C}$ freezer for 24 hours to allow freezing at a rate of approximately $1^{\circ} \mathrm{C} /$ minute, and then it was placed into liquid nitrogen and stored until thawing. The ovaries of the vitrification group (VIT) were processed with a commercial kit (Vit Kit(r) - Freeze, Irvine Scientific, California). The ovaries were immersed in the equilibrium solution containing $7.5 \%$ ethylene glycol (EG) and $7.5 \%$ dimethyl sulfoxide (DMSO) in DPBS supplemented with $20 \%$ FBS for $10 \mathrm{~min}$ at room temperature, and then transferred to a vitrification solution (15\% EG, $15 \%$ DMSO and $0.5 \mathrm{M}$ sucrose) for $2 \mathrm{~min}$, and were then placed on a piece of sterile gauze to remove excess medium and were then immediately frozen in liquid nitrogen $(1.5 \mathrm{~mL}$ cryovials).

\section{Thawing}

After 30 days of storage, the cryovials were removed from the cryotank and placed into a water bath at $37^{\circ} \mathrm{C}$ for 2 to 3 min to allow complete thawing. Slow-Freeze ovaries was rinsed in DMEM medium supplemented with decreasing concentrations of sucrose $(0.5,0.25,0.1 \mathrm{M})$ for approximately 5 minutes in each washing step. After these steps to wash out the cryoprotectant, the ovary samples were processed for further viability tests. The ovaries submitted to the vitrification process were quickly removed from the liquid nitrogen and fully immersed in the $37^{\circ} \mathrm{C}$ water bath for 3 seconds. The ovary was placed directly into the thawing solution (1 M sucrose, $20 \%$ DSS and Gentamicin in $\mathrm{M}-199$ medium) and incubated for $1 \mathrm{~min}$. After that it was transferred to a dilution solution ( $0.5 \mathrm{M}$ sucrose, $20 \%$ DSS, Gentamicin in M-199 medium), incubated for 4 min and finally transferred to the rinsing solution (20\% DSS, Gentamicin, in M-199 Medium) and incubated for $4 \mathrm{~min}$.

\section{Histological Analysis}

The ovary tissues were removed, fixed in formalin, embedded in paraffin and stained with hematoxylin and eosin.

\section{Immunohistochemical Analysis}

The germline MVH/DDX4 stem cell markers' expression was analyzed in ovary samples by immunohistochemistry. Briefly, the sections were incubated overnight at $4^{\circ} \mathrm{C}$ with a polyclonal rabbit antibody anti-DDX4 (Abcam, Cambridge) at a dilution of 1: 200. After the incubation interval, the sections were rinsed and incubated with the goat anti-rabbit IgG $(\mathrm{H}+\mathrm{L})$ HRP (Millipore, Massachusetts) detection system at a dilution of $1: 200$. The reaction was finally developed with Liquid DAB (Dako, California), according to the manufacturer's recommendations.

\section{Estrous cycle detection}

The females were submitted to vaginal cytological analysis before euthanasia, as described by Ceschin et al. (2004), in order to confirm the estrous cycle stage. Vaginal suspensions were collected in $0.5 \% \mathrm{NaCl}(0.25 \mathrm{~mL})$, and the smears were evaluated according to Cooper et al. (1998).

\section{Follicular Classification}

The follicles were classified according to the modified criteria published by Oktay et al. (1998) as follows: the follicles were analyzed and categorized as primordial, primary, pre antral and antral. Primordial follicles were identified as normal, even when they had cytoplasmic and/or irregular contour vacuolization, since such characteristics were considered reversible.

\section{Statistics}

The data was expressed as medians, percentages, quartiles, and ranges. Statistical comparisons were performed using the One-Way ANOVA for parametric variables, $p<.05$ was considered statistically significant. Statistical evaluations were performed using the PASW 18.0 software.

\section{RESULTS}

\section{Estrus cycle and body weight analysis}

The estrus cycle phase and body weight $(29.29 \pm 2.9 \mathrm{~g})$ were evaluated and presented similar results (Figure 1 ).

\section{Histological evaluation}

Hematoxylin and eosin slides were prepared to evaluate the presence of primordial, primary, pre antral and antral follicles. When the samples were submitted to slow freezing or vitrification processes a similar morphology was found among primordial, primary and pre antral follicles after the thawing/warming process. On the other hand when antral follicles were evaluated, we detected a significantly higher number of these structures on ovary samples submitted to the vitrification process $(p=0.004)$ (Figure 2$)$.

\section{Immunohistochemistry for MVH cells}

The MVH expression in frozen/thawed ovaries was assessed by immunohistochemistry. The $\mathrm{MVH}+$ and $\mathrm{MVH}-$ follicles were counted and compared with the total number of follicles found in each ovary sample from different groups (Figures 3 and 4). Total cells and total MVH positive cells were similar in different groups. When negative and positive MVH follicles where evaluated, we noticed a higher rate of negative MVH cells (no stained cells) on the ovaries submitted to the slow freeze process.

\section{DISCUSSION}

Ovarian tissue cryopreservation is the primary treatment currently available to women at risk of losing their 


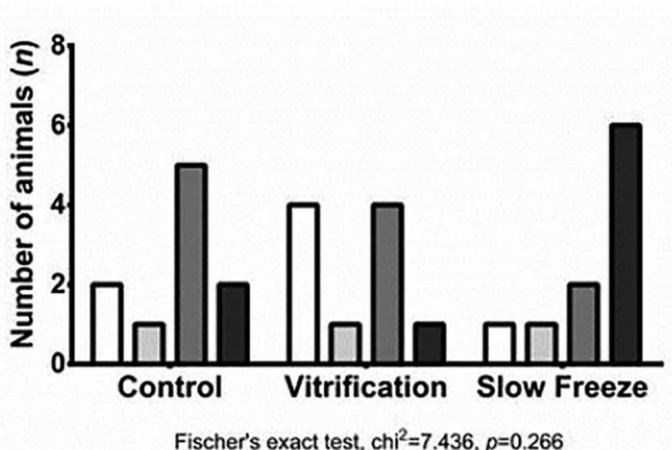

A

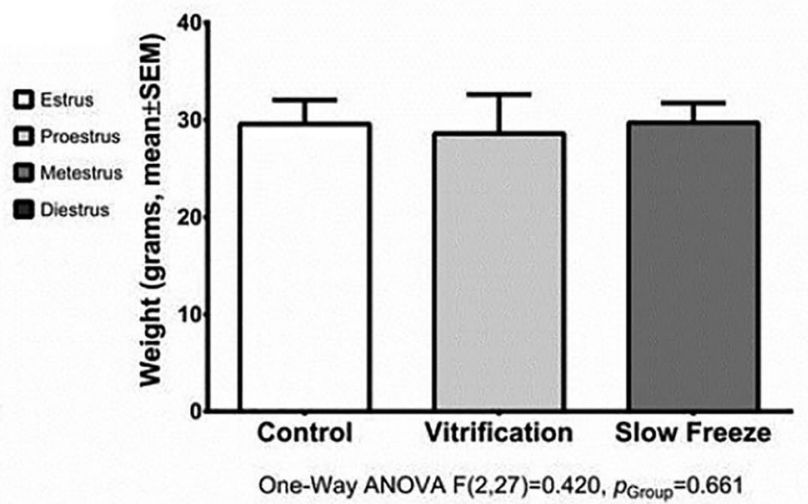

B

Figure 1. A. No statistical difference in the estrus cycle phase among the groups $(p=0.266)$. B. No statistical difference in body weight among the groups $(p=0.661)$.

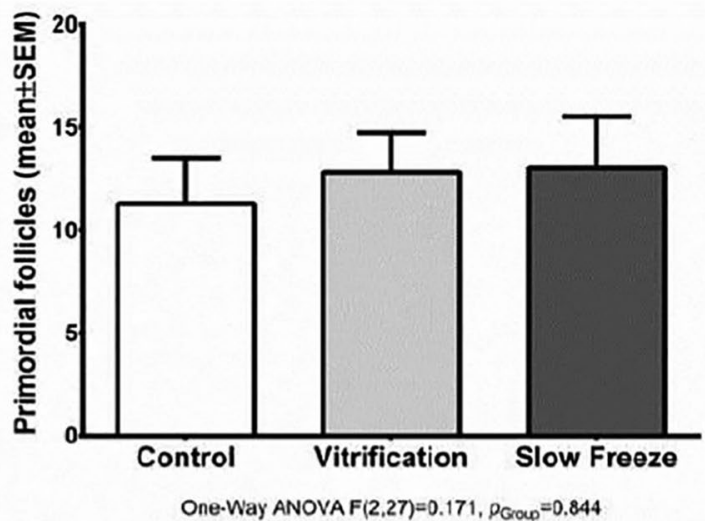

A

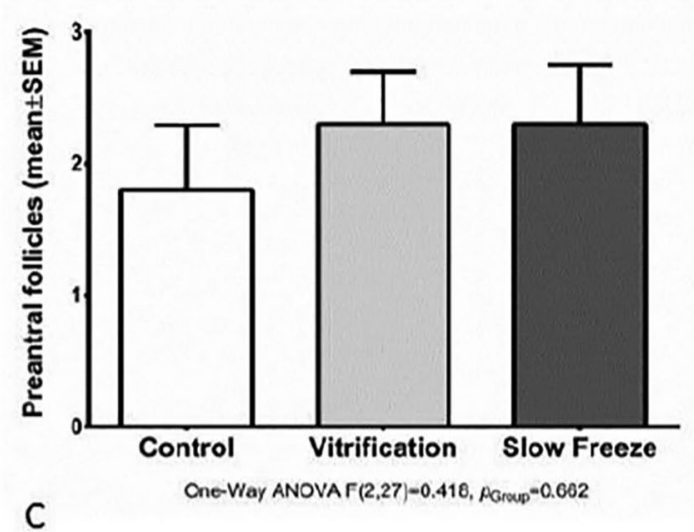

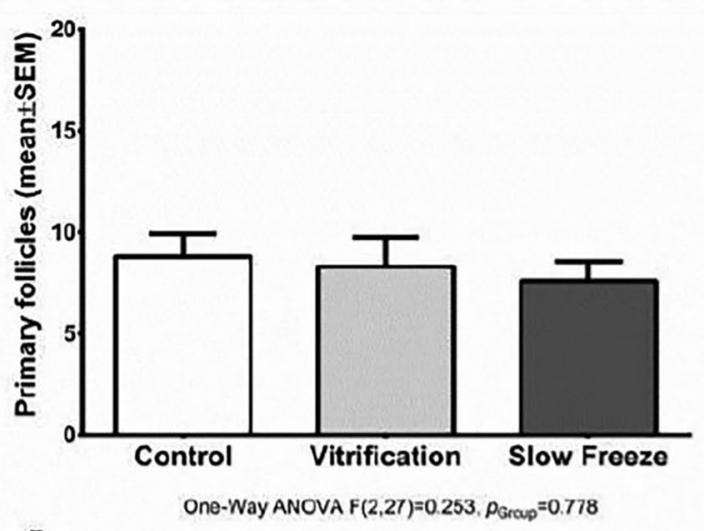

B

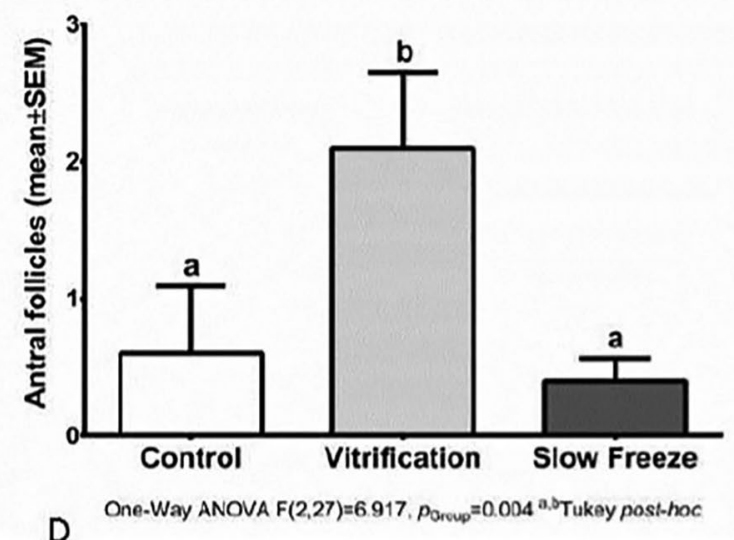

Figure 2. Number of follicles: primordial (A), primary (B), preantral (C) and antral (D) quantified from the hematoxylin and eosin technique. ab. Different letters indicate statistical difference

ovarian function due to cytotoxic therapy or radiotherapy. Its effectiveness is still fairly low. Around 15 live births have been reported (Bastings et al., 2016) since the introduction of this method, as an experimental procedure for more than 10 years (Oktay \& Karlikaya, 2000), and the first healthy baby was born in 2004 (Donnez et al., 2004). Cell damage induced by ice crystals formation and how to optimize the ovarian transplantation procedure are major questions to address in order to increase the fertility rate after transplantation with cryopreserved ovaries.

Several animal models could be used to optimize cryopreservation protocols for human use. Sheep is the animal model that has been extensively used in ovarian cryopreservation research (Baird et al., 1999; Almodin et al., 2004), 


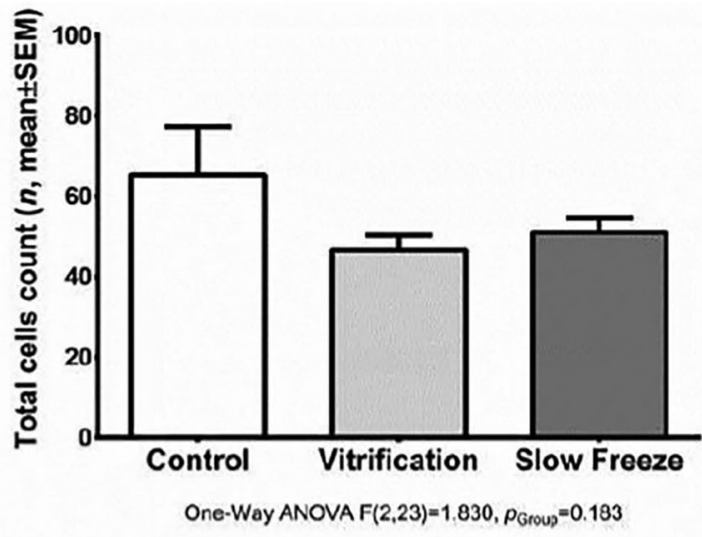

A

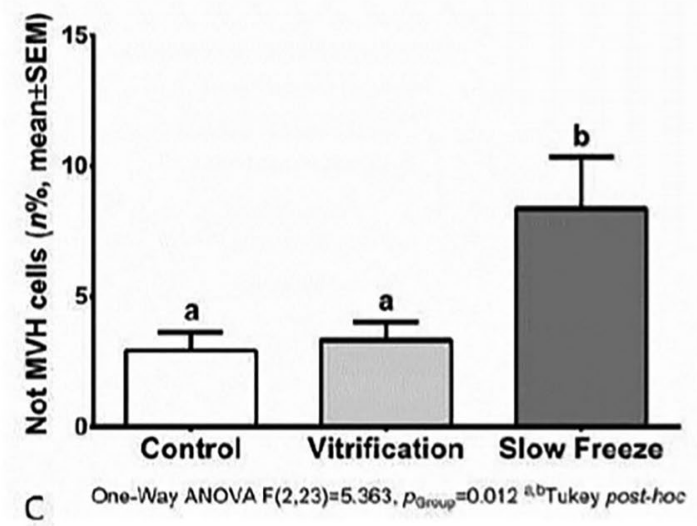

Figure 3. A: No statistical difference among groups in total cell count number $(p=0.183)$. B: No statistical difference in total follicles count $(p=0.153)$. C: Statistical difference among groups in percentage number of $\mathrm{MVH}+$. Slow freeze group had a higher number of unstained cells $(p=0.012)$.
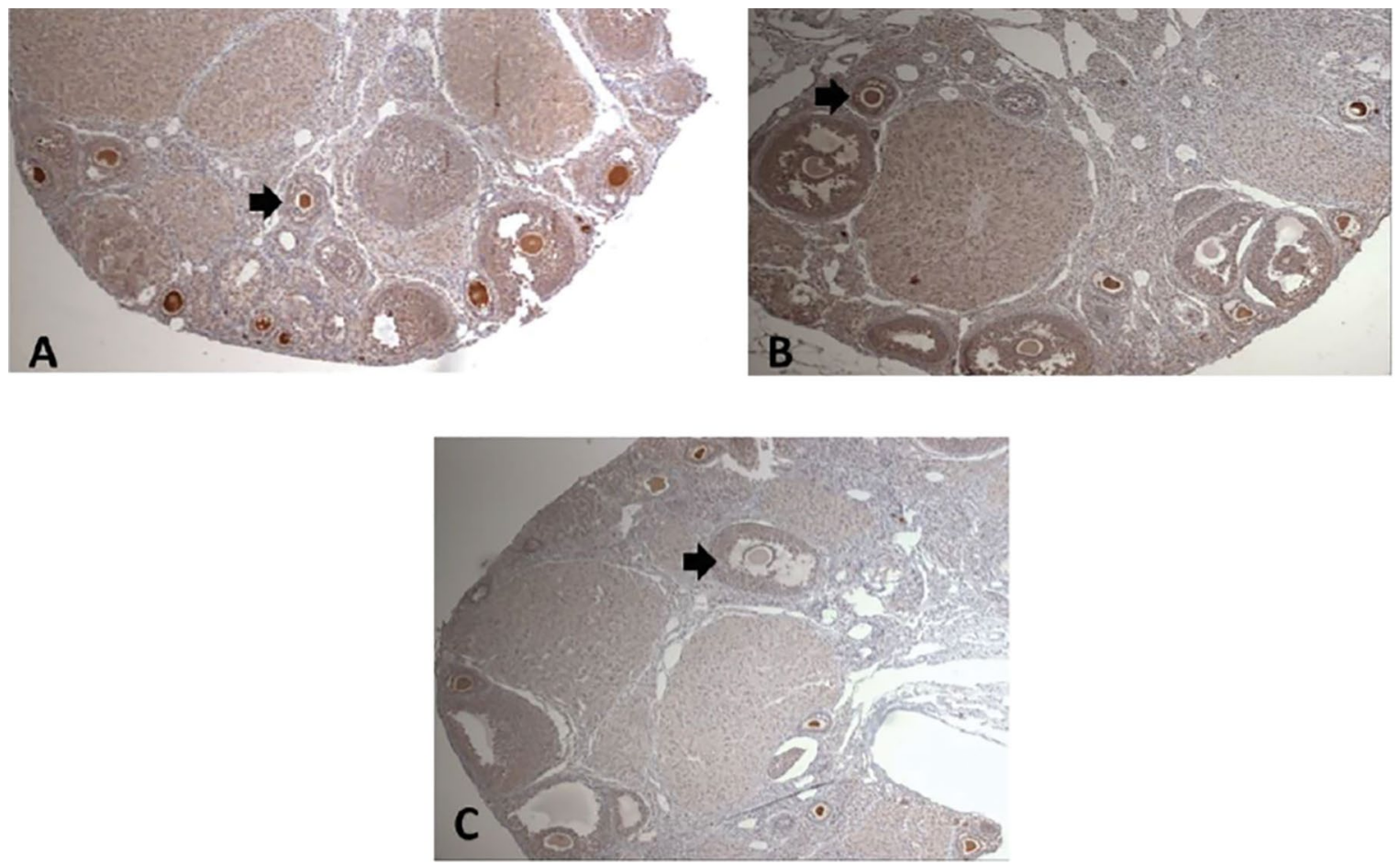

Figure 4. Immunohistochemical (IHC) sections from ovaries showing viable follicles. A: Control Group IHC for MVH+ Cells. B: Vitrification Group IHC for MVH+ Cells and C: Slow Freeze Group IHC for MVH+ Cells. Magnification 40x 
considering ovine ovary size and because these animals have mono/diovulatory cycles. However, this experimental model is expensive when compared to rodent models and inconvenient to work with. A murine model has many advantages as an experimental model for research given that it is a small and inexpensive animal with high reproductive efficiency. Moreover, knowledge about ovarian function in mice, especially folliculogenesis, is well-reported (Faire et al., 2015). The rat ovary is nearly thirty-eight times smaller than human ovaries, the primordial follicle pool distribution within ovary structure is somewhat different, and these characteristics must be taken into consideration (Faire et al., 2015). DMSO has been widely used as cryoprotectant to preserve ovarian tissue, despite several others such as ethylene glycol, which has also shown effectiveness in ovarian fertility preservation procedures, being used in experimental and clinical applications (Lee et al., 2015).

The aim of this study was to compare two different cryopreservation protocols for mice ovaries in order to assess follicle viability and MVH expression after vitrification or non-automated slow freezing processes. Ovarian tissue cryopreservation efficiency is defined as the amount of viable primordial and primary ovarian follicles detected in the processed ovarian tissue, where these structures are potentially able to generate mature oocytes in adequate conditions.

In the present study, we compared the efficacy of two cryopreservation methods, applying a specific cryoprotectant solution to each of them. Vitrification was performed applying EG and DMSO (v/v), and the non-automated slow freezing process was performed with an EG containing the cryoprotectant solution.

Regarding the histological evaluation, no significant difference was found in the rate of viable primordial, primary and pre antral follicles in the control group (92.7\%), after thawing/warming in the slow-freezing and vitrification groups, with $89.7 \%$ and $91.5 \%$ of viable follicles, respectively. On the other hand the number of antral follicles was significantly higher in ovary tissues submitted to the vitrification process $(p=0.004)$ (Figure 2$)$. This important result was probably due to the lower embryonic cell toxicity and higher cell membrane permeability of EG (Miyamoto \& Ishibashi, 1978). Comparing four different cryoprotectant agents (Propanediol, Glycerol, DMSO, EG), Lucci et al. (2004) demonstrate more effective outcomes with DMSO- and PROH-based cryoprotectant agents, which preserved the structural integrity of somatic and germ cells. This difference can be explained due to interspecies peculiarities in ovarian tissue; probably bovine follicles are more sensitive to the EG toxic effects than other species. Furthermore, EG cryopreservation seems to be more effective (Candy et al., 1997) considering that it was possible to preserve $88 \%$ of morphologically normal follicles after thawing murine ovarian tissues; however, the authors warned that prolonged exposure to EG might decrease follicular viability. In another study with human ovarian tissue, $84 \%$ of follicles survived after cryopreservation in EG (Candy et al., 1997). These findings are in accordance with our results: EG demonstrated to be less toxic as a freezing solution, as shown by its superior preservation rates of ovarian tissue structural integrity. In addition, we found a significant number of antral follicles when ovary samples were cryopreserved by the vitrification process $(p=0.04)$. In parallel, the group of experimental females was analyzed, and $80 \%$ of them were in the estrous phase, which corresponds to an ovulatory phase with increased follicular growth, or in metaestrus phase, which corresponds to the period exactly after ovulation, although there is no statistically significant difference among different analyzed cryopreservation ovary tissue processes when oestrus phases were compared.
In the last decade, several studies have yielded controversial results when comparing the conventional freezing process with vitrification (Newton et al., 1996; Keros et al., 2009; Oktem et al., 2011). Isachenko et al. (2009) tested vitrification versus the conventional freezing process of human ovarian tissue and concluded that conventional freezing is a better technique, since the preserved tissue conserves a higher development potential.

Based on the study by Zou et al. (2009), which was able to transplant ovarian stem cells into mice, and obtain a viable offspring, and Terraciano et al. (2014), which compared the ADSC or MVH cell transplant to restore fertility in mice with significant positive results, our initial purpose was to compare the MVH expression in different types of freezing processes for subsequent cell transplantation. In order to assess the MVH expression in frozen/thawed ovaries, we performed immunohistochemistry. MVH is the homologue of the Drosophila vasa gene, which is specifically expressed in all germ cell lineages and is known as a specific marker of reproductive cells (Encinas et al., 2012; $\mathrm{Li}$ et al., 2014). Therefore, in general, MVH is used as the marker of germ stem cells. In our study the $\mathrm{MVH}+$ and $\mathrm{MVH}$ - follicles were counted and compared with the total number of follicles and we found a higher number of unstained cells in the slow freeze group $(p=0.012)$. Our data showed that vitrification of ovarian tissue using combination of cryoprotectant agents (EG with DMSO) had no harmful effect on the morphology and $\mathrm{MVH}$ expression in the ovarian tissue, where the cell structure is complex.

The major difficulty with vitrification protocols is its high toxicity, due to the high concentration of cryoprotectants used, which can cause severe osmotic shock and compromise tissue survival after thawing (Rall \& Fahy, 1985; Rall, 1987; Vajta et al., 1998). Toxicity reduction can be achieved using a combination of two cryoprotectants and a gradual exposure of the cells to the concentrated solutions prior to cooling. This technique was used in this study, similarly to other studies (Hasegawa et al., 2004; Liebermann et al., 2002). Although both protocols showed similar results in the histological analysis for follicular counts, the vitrification protocol was significantly better to preserve the ovarian stem cell population.

Ceschin et al. (2004) using IHC analysis with Ki67 concluded that although both conventional freezing and vitrification were feasible methods for ovarian tissue cryopreservation, vitrification was associated with the recovery of a greater number of potentially viable primordial follicles in rats, similarly to ours conclusions.

\section{SUPPORT}

This study was funded by Fundo de Incentivo à Pesquisa e Eventos - FIPE - Hospital de Clínicas de Porto Alegre.

\section{CONFLICT OF INTEREST}

There is no conflict of interest to declare.

\section{Corresponding author:}

Paula Barros Terraciano

Hospital de Clínicas de Porto Alegre

Centro de Pesquisa Experimental

Laboratório de Embriologia e Diferenciação Celular

Porto Alegre, RS, Brazil.

E-mail: pterraciano@hcpa.edu.br

\section{REFERENCES}

Ackermann CL, Asa CS, Krisher R, Bauman K, Casey S, Lopes MD. Evaluation of follicular growth and tissue viability in vitrified/warmed domestic dog ovaries after in vitro culture. Reprod Domest Anim. 2017;52:77-81. PMID: 27758003 DOI: $10.1111 /$ rda. 12823 
Almodin CG, Minguetti-Camara VC, Meister H, Ceschin $A P$, Kriger $E$, Ferreira JO. Recovery of natural fertility after grafting of cryopreserved germinative tissue in ewes subjected to radiotherapy. Fertil Steril. 2004;81:160-4. PMID: 14711560 DOI: $10.1016 /$ j.fertnstert.2003.05.023

Bagwell JN, Chihal HJ, Peppler RD. Fine structure of the corpus luteum of the autografted ovary in the rat. Cell Tissue Res. 1976;171:375-9. PMID: 975218 DOI: 10.1007/ BF00224661

Baird DT, Webb R, Campbell BK, Harkness LM, Gosden RG. Long-term ovarian function in sheep after ovariectomy and transplantation of autografts stored at $-196 \mathrm{C}$. Endocrinology. 1999;140:462-71. PMID: 9886858 DOI: 10.1210/ endo.140.1.6453

Bastings L, Westphal JR, Beerendonk CC, Bekkers RL, Zusterzeel PL, Hendriks JC, Braat DD, Peek R. Clinically applied procedures for human ovarian tissue cryopreservation result in different levels of efficacy and efficiency. J Assist Reprod Genet. 2016;33:1605-14. PMID: 27714478 DOI: $10.1007 / \mathrm{s} 10815-016-0816-z$

Bedaiwy MA, Falcone T. Whole ovary transplantation. Clin Obstet Gynecol. 2010;53:797-803. PMID: 21048446 DOI: 10.1097/GRF.0b013e3181f97c94

Bromer JG, Patrizio P. Fertility preservation: the rationale for cryopreservation of the whole ovary. Semin Reprod Med. 2009;27:465-71. PMID: 19806515 DOI: $10.1055 / \mathrm{s}-$ 0029-1241056

Candy $\mathrm{CJ}$, Wood MJ, Whittingham DG. Effect of cryoprotectants on the survival of follicles in frozen mouse ovaries. J Reprod Fertil. 1997;110:11-9. PMID: 9227352 DOI: $10.1530 /$ jrf.0.1100011

Ceschin AP, Biondo-Simões MLP, Thomaz BAC, Totsugui J. Avaliação hormonal indireta e estudo da preservação folicular em tecido ovariano autólogo transplantado para região inguinal em ratos. Acta Cir Bras. 2004;19:27-30. DOI: $10.1590 / S 0102-86502004000100004$

Cooper RL, Goldman JM, Vandenbergh JG. Monitoring of the estrous cycle in laboratory rodent by vaginal lavage. In: Heindel JJ, Chapin RE, eds. Methods in Toxicology: Female Reproductive Toxicology. San Diego: Academic Press; 1998. p. 45-56.

Demeestere I, Simon P, Emiliani S, Delbaere A, Englert Y. Orthotopic and heterotopic ovarian tissue transplantation. Hum Reprod Update. 2009;15:649-65. PMID: 19474206 DOI: $10.1093 /$ humupd/dmp021

Donnez J, Dolmans MM, Demylle D, Jadoul P, Pirard C, Squifflet J, Martinez-Madrid B, van Langendonckt A. Livebirth after orthotopic transplantation of cryopreserved ovarian tissue. Lancet. 2004;364:1405-10. PMID: 15488215 DOI: $10.1016 / S 0140-6736(04) 17222-X$

Donnez J, Silber S, Andersen CY, Demeestere I, Piver P, Meirow D, Pellicer A, Dolmans MM. Children born after autotransplantation of cryopreserved ovarian tissue. A review of 13 live births. Ann Med. 2011;43:437-50. PMID: 21226660 DOI: $10.3109 / 07853890.2010 .546807$

Dorsch M, Wedekind D, Kamino K, Hedrich HJ. Orthotopic transplantation of rat ovaries as a tool for strain rescue. Lab Anim. 2004;38:307-12. PMID: 15207042 DOI: $10.1258 / 002367704323133691$
Encinas G, Zogbi C, Stumpp T. Detection of four germ cell markers in rats during testis morphogenesis: differences and similarities with mice. Cells Tissues Organs. 2012;195:44355. PMID: 21893932 DOI: 10.1159/000329245

Faire M, Skillern A, Arora R, Nguyen DH, Wang J, Chamberlain C, German MS, Fung JC, Laird DJ. Follicle dynamics and global organization in the intact mouse ovary. Dev Biol. 2015;403:69-79. PMID: 25889274 DOI: 10.1016/j. ydbio.2015.04.006

Gosden RG. Low temperature storage and grafting of human ovarian tissue. Mol Cell Endocrinol. 2000;163:125-9. PMID: 10963884 DOI: 10.1016/S0303-7207(99)00248-8

Hasegawa A, Hamada Y, Mehandjiev T, Koyama K. In vitro growth and maturation as well as fertilization of mouse preantral oocytes from vitrified ovaries. Fertil Steril. 2004;81:824-30. PMID: 15019816 DOI: $10.1016 / j$.fertnstert.2003.08.028

Imhof M, Bergmeister H, Lipovac M, Rudas M, Hofstetter G, Huber J. Orthotopic microvascular reanastomosis of whole cryopreserved ovine ovaries resulting in pregnancy and live birth. Fertil Steril. 2006;85:1208-15. PMID: 16616094 DOI: $10.1016 /$ j.fertnstert.2005.11.030

Isachenko V, Lapidus I, Isachenko $E$, Krivokharchenko A, Kreienberg R, Woriedh M, Bader M, Weiss JM. Human ovarian tissue vitrification versus conventional freezing: morphological, endocrinological, and molecular biological evaluation. Reproduction. 2009;138:319-27. PMID: 19439559 DOI: $10.1530 / R E P-09-0039$

Israely $T$, Nevo $N$, Harmelin A, Neeman M, Tsafriri A. Reducing ischaemic damage in rodent ovarian xenografts transplanted into granulation tissue. Hum Reprod. 2006;21:1368-79. PMID: 16459346 DOI: 10.1093/hum$\mathrm{rep} / \mathrm{del} 010$

Jadoul P, Donnez J, Dolmans MM, Squifflet J, Lengele B, Martinez-Madrid B. Laparoscopic ovariectomy for whole human ovary cryopreservation: technical aspects. Fertil Steril. 2007;87:971-5. PMID: 17173904 DOI: 10.1016/j. fertnstert.2006.10.012

Kagawa N, Silber S, Kuwayama M. Successful vitrification of bovine and human ovarian tissue. Reprod Biomed Online. 2009;18:568-77. PMID: 19401001 DOI: 10.1016/ S1472-6483(10)60136-8

Keros V, Xella S, Hultenby K, Pettersson K, Sheikhi M, Volpe A, Hreinsson J, Hovatta O. Vitrification versus controlled-rate freezing in cryopreservation of human ovarian tissue. Hum Reprod. 2009;24:1670-83. PMID: 19359339 DOI: $10.1093 /$ humrep/dep079

Kim SS, Yang HW, Kang HG, Lee HH, Lee HC, Ko DS, Gosden RG. Quantitative assessment of ischemic tissue damage in ovarian cortical tissue with or without antioxidant (ascorbic acid) treatment. Fertil Steril. 2004;82:679-85. PMID: 15374714 DOI: $10.1016 /$ j.fertnstert.2004.05.022

Lee JR, Youm HW, Lee HJ, Jee BC, Suh CS, Kim SH. Effect of antifreeze protein on mouse ovarian tissue cryopreservation and transplantation. Yonsei Med J. 2015;3:778-84. PMID: 25837185 DOI: 10.3349/ymj.2015.56.3.778 
Li R, Thorup J, Sun C, Cortes D, Southwell B, Hutson J. Immunofluorescent analysis of testicular biopsies with germ cell and Sertoli cell markers shows significant MVH negative germ cell depletion with older age at orchiopexy. J Urol. 2014;191:458-64. PMID: 24012581 DOI: 10.1016/j. juro.2013.08.075

Liebermann J, Nawroth F, Isachenko V, Isachenko E, Rahimi G, Tucker MJ. Potential Importance of Vitrification in Reproductive Medicine. Biol Reprod. 2002;67:1671-80. PMID: 12444040 DOI: 10.1095/biolreprod.102.006833

Liu J, Van der Elst J, Van den Broecke R, Dhont M. Early massive follicle loss and apoptosis in heterotopically grafted newborn mouse ovaries. Hum Reprod. 2002;17:60511. PMID: 11870111 DOI: $10.1093 /$ humrep/17.3.605

Lucci CM, Kacinskis MA, Lopes LH, Rumpf R, Bao SN. Effect of different cryoprotectants on the structural preservation of follicles in frozen zebu bovine (Bos indicus) ovarian tissue. Theriogenology. 2004;61:1101-14. PMID: 15036998 DOI: $10.1016 /$ j.theriogenology.2003.06.004

Martinez-Madrid B, Camboni A, Dolmans MM, Nottola S, Van Langendonckt A, Donnez J. Apoptosis and ultrastructural assessment after cryopreservation of whole human ovaries with their vascular pedicle. 2007;87:1153-65. PMID: 17239875 DOI: 10.1016/j.fertnstert.2006.11.019

Meirow D, Nugent D. The effects of radiotherapy and chemotherapy on female reproduction. Hum Reprod Update. 2001 ; 7:535-43. PMID: 11727861 DOI: 10.1093/humupd/7.6.535

Miyamoto $\mathrm{H}$, Ishibashi $\mathrm{T}$. The protective action of glycols against freezing damage of mouse and rat embryos. J Reprod Fertil. 1978;2:427-32. PMID: 722690 DOI: 10.1530/ jrf.0.0540427

Newton H, Aubard Y, Rutherford A, Sharma V, Gosden R. Low temperature storage and grafting of human ovarian tissue. Hum Reprod. 1996;11:1487-91. PMID: 8671490 DOI: 10.1093 /oxfordjournals. humrep.a019423

Nugent D, Newton H, Gallivan L, Gosden RG. Protective effect of vitamin $E$ on ischaemia-reperfusion injury in ovarian grafts. J Reprod Fertil. 1998;114:341-6. PMID: 10070363 DOI: $10.1530 /$ jrf.0.1140341

Oktay K, Newton H, Aubard Y, Salha O, Gosden RG. Cryopreservation of human oocytes and ovarian tissue: an emerging technology? Fertil Steril. 1998;69:1-7. PMID: 9457923 DOI: 10.1016/S0015-0282(97)00207-0

Oktay K, Karlikaya G. Ovarian function after transplantation of frozen, banked autologous ovarian tissue. $\mathrm{N}$ Engl J Med. 2000;342:1919. PMID: 10877641 DOI: 10.1056/ NEJM200006223422516

Oktem O, Alper E, Balaban B, Palaoglu E, Peker K, Karakaya C, Urman B. Vitrified human ovaries have fewer primordial follicles and produce less antimüllerian hormone than slow-frozen ovaries. Fertil Steril. 2011;95:2661-4.e1. PMID: 21300348 DOI: 10.1016/j.fertnstert.2010.12.057
Rall WF, Fahy GM. Ice-free cryopreservation of mouse embryos at -196 degrees $C$ by vitrification. Nature. 1985;313:573-5. PMID: 3969158 DOI: $10.1038 / 313573 a 0$

Rall WF. Factors affecting the survival of mouse embryos cryopreserved by vitrification. Cryobiology. 1987;24:387402. PMID: 3652721 DOI: 10.1016/0011-2240(87)900423

Sapmaz E, Ayar A, Celik H, Sapmaz T, Kilic N, Yasar MA. Effects of melatonin and oxytetracycline in autologous intraperitoneal ovary transplantation in rats. Neuro Endocrinol Lett. 2003;24:350-4. PMID: 14647012

Schnorr J, Oehninger S, Toner J, Hsiu J, Lanzendorf S, Williams R, Hodgen G. Functional studies of subcutaneous ovarian transplants in non-human primates: steroidogenesis, endometrial development, ovulation, menstrual patterns and gamete morphology. Hum Reprod. 2002;17:6129. PMID: 11870112 DOI: 10.1093/humrep/17.3.612

Sheikhi M, Hultenby K, Niklasson B, Lundqvist M, Hovatta $O$. Clinical grade vitrification of human ovarian tissue: an ultrastructural analysis of follicles and stroma in vitrified tissue. Hum Reprod. 2011:594-603. PMID: 21217141 DOI: $10.1093 /$ humrep/deq357

Silber SJ, Grudzinskas G, Gosden RG. Successful pregnancy after microsurgical transplantation of an intact ovary. N Engl J Med. 2008;359:2617-8. PMID: 19073987 DOI: 10.1056/NEJMc0804321

Sugimoto M, Maeda S, Manabe N, Miyamoto H. Development of infantile rat ovaries autotransplanted after cryopreservation by vitrification. Theriogenology. 2000;53:1093-103. PMID: 10798487 DOI: $10.1016 /$ S0093-691X(00)00255-7

Terraciano P, Garcez T, Ayres L, Durli I, Baggio M, Kuhl $\mathrm{CP}$, Laurino C, Passos E, Paz AH, Cirne-Lima E. Cell therapy for chemically induced ovarian failure in mice. Stem Cells Int. 2014;2014:720753. PMID: 25548574 DOI: $10.1155 / 2014 / 720753$

Vajta G, Holm P, Kuwayama M, Booth PJ, Jacobsen $H$, Greve $\mathrm{T}$, Callesen $\mathrm{H}$. Open pulled straw (OPS) vitrification: a new way to reduce cryoinjuries of bovine ova and embryos. Mol Reprod Dev. 1998;51:53-8. PMID: 9712317 DOI: $\quad 10.1002 /(S I C I) 1098-2795(199809) 51: 1<53:$ :AIDMRD6>3.0.CO;2-V

Wang $X$, Chen $H$, Yin $H$, Kim SS, Lin Tan S, Gosden RG. Fertility after intact ovary transplantation. Nature. 2002;415:385. PMID: 11807540 DOI: $10.1038 / 415385 a$

Weissman A, Gotlieb L, Colgan T, Jurisicova A, Greenblatt EM, Casper RF. Preliminary experience with subcutaneous human ovarian cortex transplantation in the NOD-SCID mouse. Biol Reprod. 1999;60:1462-7. PMID: 10330106 DOI: $10.1095 /$ biolreprod60.6.1462

Zou K, Yuan Z, Yang Z, Luo H, Sun K, Zhou L, Xiang J, Shi L, Yu Q, Zhang Y, Hou R, Wu J. Production of offspring from a germline stem cell line derived from neonatal ovaries. Nat Cell Biol. 2009;11:631-6. PMID: 19363485 DOI: $10.1038 /$ ncb 1869 